\title{
Leptin Receptor Signaling in the Hypothalamus Regulates Hepatic Autonomic Nerve Activity via Phosphatidylinositol 3-Kinase and AMP-Activated Protein Kinase
}

\author{
Mamoru Tanida, ${ }^{1,4}$ Naoki Yamamoto, ${ }^{2}$ DDonald A. Morgan, ${ }^{3}$ Yasutaka Kurata, ${ }^{1}$ Toshishige Shibamoto, ${ }^{1}$ \\ and Kamal Rahmouni ${ }^{3,4,5}$ \\ ${ }^{1}$ Department of Physiology II, Kanazawa Medical University, Uchinada, Ishikawa 920-0293, Japan, ${ }^{2}$ College of Pharmacology, Hokuriku University, \\ Kanazawa, Ishikawa 920-1180, Japan, and ${ }^{3}$ Department of Pharmacology, ${ }^{4}$ Department of Internal Medicine, and ${ }^{5}$ Fraternal Order of Eagles Diabetes \\ Research Center, University of Iowa Carver College of Medicine, Iowa City, Iowa 52242
}

Leptin action in the brain has emerged as an important regulator of liver function independently from its effects on food intake and body weight. The autonomic nervous system plays a key role in the regulation of physiological processes by leptin. Here, we used direct recording of nerve activity from sympathetic or vagal nerves subserving the liver to investigate how brain action of leptin controls hepatic autonomic nerve activity. Intracerebroventricular (ICV) administration of leptin activated hepatic sympathetic traffic in rats and mice in dose- and receptor-dependent manners. The hepatic sympatho-excitatory effects of leptin were also observed when leptin was microinjected directly into the arcuate nucleus (ARC), but not into the ventromedial hypothalamus (VMH). Moreover, using pharmacological and genetic approaches, we show that leptin-induced increase in hepatic sympathetic outflow depends on PI3K but not AMP-activated protein kinase (AMPK), STAT3, or ERK1/2. Interestingly, ICV leptin also increased hepatic vagal nerve activity in rats. We show that this response is reproduced by intra-ARC, but not intra- $\mathrm{VMH}$, leptin administration and requires PI3K and AMPK. We conclude that central leptin signaling conveys the information to the liver through the sympathetic and parasympathetic branches of the autonomic nervous system. Our data also provide important insight into the molecular events underlying leptin's control of hepatic autonomic nerve activity by implicating PI3K and AMPK pathways.

Key words: AMPK; autonomic function; leptin; liver; PI3K

\section{Introduction}

The adipocyte hormone leptin acts in the CNS to promote weight loss by decreasing food intake and enhancing energy expenditure (Friedman and Halaas, 1998; Gautron and Elmquist, 2011). Leptin modulates several other physiological processes independently from its effects on food intake and energy expenditure (Gautron and Elmquist, 2011). For instance, growing evidence implicates leptin in the regulation of glucose homeostasis and insulin sensitivity in peripheral tissues (Morton and Schwartz, 2011; Coppari and Bjørbæk, 2012). Indeed, leptin treatment is effective to normalize blood glucose levels in rodent models of

\footnotetext{
Received May 5, 2014; revised 0ct. 31, 2014; accepted Nov. 3, 2014.

Author contributions: M.T. and K.R. designed research; M.T., N.Y., D.A.M., Y.K., and T.S. performed research; M.T., Y.K., T.S., and K.R. contributed unpublished reagents/analytic tools; M.T., N.Y., D.A.M., Y.K., T.S., and K.R. analyzed data; M.T. and K.R. wrote the paper.

This work was supported by grants from the Ministry of Education, Culture, Sports, Science, and Technology of Japan (Grant-in-Aid for Young Scientists 23689008) and the Takeda Science Foundation to M.T.; and by National Institutes of Health Grant HL084207 and American Heart Association Award 14EIA18860041 to K.R.

The authors declare no competing financial interests.

Correspondence should be addressed to either of the following: Dr. Mamoru Tanida, Department of Physiology II, Kanazawa Medical University, 1-1 Daigaku, Uchinada, Ishikawa 920-0293, Japan, E-mail: mtanidakanazawamed.ac.jp; or Dr. Kamal Rahmouni, Department of Pharmacology, University of lowa Carver College of Medicine, 2-248 BSB, lowa City, IA 52242. E-mail: kamal-rahmouni@uiowa.edu.

DOI:10.1523/JNEUROSCI.1828-14.2015

Copyright $\odot 2015$ the authors $\quad 0270-6474 / 15 / 350474-11 \$ 15.00 / 0$
}

type 1 and type 2 diabetes and in patients with lipodystrophy (Morton and Schwartz, 2011; Coppari and Bjørbæk, 2012). Notably, cerebroventricular or intrahypothalamic administration of leptin is sufficient to normalize glucose in diabetic animals, indicating that the glucose-lowering effect of leptin is centrally mediated (Hidaka et al., 2002; Fujikawa et al., 2010; Toda et al., 2013).

Improvement in liver function, such as normalization of elevated hepatic glucose production, represents a major mechanism by which CNS leptin signaling exerts its glucose-reducing effects (Morton and Schwartz, 2011). CNS action of leptin was also found to regulate directly hepatic triglyceride storage with pathophysiological implications (Warne et al., 2011). Indeed, impairment in CNS leptin signaling appears to promote hepatic steatosis independent of hyperphagia and obesity (Warne et al., 2011). Together, these data provide compelling evidence that CNS leptin regulates several aspects of liver function.

The long form of the leptin receptor (LepRb), which is lacking in $\mathrm{db} / \mathrm{db}$ mice (Chen et al., 1996), is expressed in several brain nuclei with higher expression in the hypothalamic arcuate nucleus (ARC; Morton and Schwartz, 2011). Leptin binding to the LepRb leads to the activation of several intracellular signaling pathways (Myers et al., 2008; Coppari and Bjørbæk, 2012) including signal transducer and activator of transcription 3 (STAT3), extracellular signal-regulated kinase 1/2 (ERK1/2), and 
phosphatidylinositol 3-kinase (PI3K; Rahmouni et al., 2009; Morton and Schwartz, 2011). In addition, hypothalamic AMPactivated protein kinase (AMPK) has emerged as a key downstream pathway in LepRb signaling and in mediating leptin effects (Minokoshi et al., 2004; Tanida et al., 2013).

Here, we used direct electrophysiological recording to investigate the effect of leptin on autonomic nerve discharges supplying the liver in rats and mice. In addition, we tested the involvement of various intracellular signal mechanisms associated with the LepRb in mediating leptin-evoked changes in hepatic autonomic nerve outflows.

\section{Materials and Methods}

Animals. Male Wistar rats (weighing 250-270 g) and C57BL/6J mice (weighing 20-23 g) were used in these studies. Animals were housed in a room maintained at $24 \pm 1^{\circ} \mathrm{C}$ and illuminated for $12 \mathrm{~h}(8: 00$ A.M. to 8:00 P.M.). In addition, we used $\mathrm{db} / \mathrm{db}$ mice and previously generated mice that bear point mutations in the LepRb $\left[\right.$ Lepr $^{L 985}$, named $l / l$ mice (Björnholm et al., 2007), and Lepr ${ }^{S 1138}$, named s/s mice (Bates et al., 2003)] or in the catalatic $\mathrm{p} 110 \alpha$ subunit of PI3K ( $110 \alpha^{\mathrm{D} 933 \mathrm{~A} / \mathrm{WT}}$ mice; Foukas et al., 2006). Heterozygous mice were bred to generate experimental mice $(l / l$, $s / s$, and $\left.110 \alpha^{\mathrm{D} 933 \mathrm{~A} / \mathrm{WT}}\right)$ and wild-type $(+/+)$ controls needed for our study. Mice were genotyped using custom-designed single-nucleotide polymorphism assays, which enabled accurate and reliable detection of each point mutation in these knock-in mouse models, as described previously (Harlan et al., 2011a, 2013).

Rats and mice had ad libitum access to standard laboratory chow and tap water and were allowed to adapt to the environment for at least 1 week before experimentation. All animal care and handling procedures were approved by the Animal Research Committees of Kanazawa Medical University and the University of Iowa.

Brain cannulation. Rats and mice were equipped with intracerebroventricular (ICV) cannulas using a stereotaxic apparatus as described previously (Hilzendeger et al., 2012; Harlan et al., 2013). Briefly, rats and mice were anesthetized by intraperitoneal injection of ketamine $(91 \mathrm{mg} /$ $\mathrm{kg})$ and xylazine $(9.1 \mathrm{mg} / \mathrm{kg})$ and placed in a stereotactic device. A stainless steel guide cannula ( 23 gauge for rats and 25 gauge for mice) with a stylet was implanted into the lateral cerebroventricular area using the indicated coordinates relative to bregma in rats $[+0.3 \mathrm{~mm}$ anteroposterior $(\mathrm{AP}),+1.4 \mathrm{~mm}$ mediolateral $(\mathrm{ML})$, and $-6.0 \mathrm{~mm}$ dorsoventral (DV) ] and mice ( $+0.3 \mathrm{~mm} \mathrm{AP},+1.0 \mathrm{~mm} \mathrm{ML}$, and $-3.0 \mathrm{~mm} \mathrm{DV})$ as reported previously (Hilzendeger et al., 2012). The third cerebroventricular area was targeted in rats as in our previous study (Tanida et al., 2013) using the following coordinates: $-1.0 \mathrm{~mm} \mathrm{AP,} 0 \mathrm{~mm} \mathrm{ML}$, and $-7.5 \mathrm{~mm}$ DV. The ARC of rats was cannulated unilaterally using a 25 gauge guide cannula with coordinates $(-2.9 \mathrm{~mm} \mathrm{AP},+2 \mathrm{~mm} \mathrm{ML}$, and $-8.6 \mathrm{~mm} \mathrm{DV}$ with a $10^{\circ}$ angle) according to the atlas of Paxinos and Watson (2005) . In the other cohort of rats, the ventromedial hypothalamus (VMH) was cannulated using the following coordinates: $-2.5 \mathrm{~mm}$ $\mathrm{AP},+0.7 \mathrm{~mm} \mathrm{ML}$, and $+9.5 \mathrm{~mm}$ DV with a $10^{\circ}$ angle.

To perform the injection, the stylet was removed from the guide cannula. An injector (a 29 gauge for ICV injection in rats or a 33 gauge for ICV injection in mice and microinjection into the ARC or VMH in rats) attached to a Hamilton syringe was inserted into the cannula. We mixed fluorescent dye (Fluorescein Isothiocyanate Dextran 7000; SigmaAldrich) with the injectate targeting the ARC or VMH to visualize the injection site (López et al., 2010). At the end of each experiment, the animal was perfused with $4 \%$ paraformaldehyde and $0.5 \%$ glutaraldehyde. To verify the accuracy of ARC and VMH injections, the brain was sectioned, and brain slices were counterstained with or without DAPI before examination.

Electrophysiological recording of liver autonomic nerve activity. Seven to ten days after recovery from brain cannulation, anesthesia was induced in both rats and mice by intraperitoneal injection of a $91 \mathrm{mg} / \mathrm{kg}$ ketamine and $9.1 \mathrm{mg} / \mathrm{kg}$ xylazine mixture. A polyethylene catheter (PE-50 for rats) or tapered micro-renathane tubing (MRE-40 for mice) was inserted into the jugular vein for intravenous injection. Blood pressure was monitored through an arterial catheter (a PE-50 catheter inserted into the left fem- oral artery in rats or a tapered MRE-40 inserted into the left carotid artery in mice). The trachea was then cannulated (using PE-240 for rats and PE-50 for mice). Each intubated animal was allowed to spontaneously breathe oxygen-enriched room air for the duration of the experimental protocol. The level of anesthesia was sustained throughout the experimental protocol by a slow infusion of $\alpha$-chloralose through the jugular vein cannulation (for rats: $50 \mathrm{mg} / \mathrm{kg}$ bolus followed by a $25 \mathrm{mg} / \mathrm{kg}$ sustaining infusion; for mice: $12 \mathrm{mg} / \mathrm{kg}$ bolus followed by a $6 \mathrm{mg} / \mathrm{kg}$ sustaining infusion). Body temperature monitored with a thermometer inserted into the rectum was maintained at $37.0-37.5^{\circ} \mathrm{C}$ using a heating pad.

Autonomic nerve activity measurements were performed as in our previous studies (Harlan et al., 2013; Tanida et al., 2013). To record liver sympathetic nerve activity (Liv-SNA) in both rats and mice, the celiac and liver branch of the ventral splanchnic nerve was identified and exposed at the level of liver artery using a dissecting microscope. To measure liver vagal nerve activity (Liv-VNA) in the rat, the hepatic branch of the ventral subdiaphragmatic vagal nerve was identified and exposed on the esophagus after incision of the abdominal midline. Liv-SNA and -VNA were recorded in separate animals. Each nerve was attached to a pair of 36 gauge stainless steel wire electrodes and quickly fixed with a silicon gel (Kwik-Sil; WPI) to prevent dehydration and for electrical insulation. After surgery, each animal was allowed to stabilize for 20-40 $\min$.

Electrical activity in each nerve was amplified 50,000-100,000 times with a band path of $100-1000 \mathrm{kHz}$ and monitored by an oscilloscope. The amplified and filtered nerve activity was converted to standard pulses by a window discriminator, which separated discharge from electrical background noise that was determined postmortem. Both the discharge rates and the neurogram were sampled with a Power-Lab analog-to-digital converter for recording and data analysis on a computer. Background noise, which was determined 30-60 min after the animal was killed, was subtracted. Nerve activity was rectified and integrated with baseline nerve activity normalized to $100 \%$.

Baseline measurements of Liv-SNA and -VNA were made 5-10 min before ICV injection of vehicle (saline, $10 \mu \mathrm{l}$ in rats, $2 \mu \mathrm{l}$ in mice) and leptin $(10 \mu \mathrm{g} / 10 \mu \mathrm{l}$ saline for rats, $2 \mu \mathrm{g} / 2 \mu \mathrm{l}$ saline for mice). The other cohort of rats received unilateral leptin injection directly into the ARC or $\mathrm{VMH}$ at a dose of $0.5 \mu \mathrm{g}$ in $0.2 \mu \mathrm{l}$ of saline. In experiments using pharmacological inhibitors, animals first received ICV U0126 (7 $\mu \mathrm{g}$ for rats, $1.4 \mu \mathrm{g}$ for mice), LY294002 (5 $\mu \mathrm{g}$ for rats, $1 \mu \mathrm{g}$ for mice), SB203580 (0.5 $\mu \mathrm{g}$ for rats, $0.1 \mu \mathrm{g}$ for mice), or vehicle followed $15 \mathrm{~min}$ later by ICV leptin or vehicle. After treatments, nerve activities were followed for $180-240 \mathrm{~min}$. At the end of the experiment, hexamethonium bromide $(10 \mathrm{mg} / \mathrm{kg}$ body weight) was administered intravenously to ensure that postganglionic efferent sympathetic nerve activity had been recorded.

Effect of direct liver autonomic nerve stimulation on blood glucose. After anesthesia was induced in both rats and mice by intraperitoneal injection of the $91 \mathrm{mg} / \mathrm{kg}$ ketamine and $9.1 \mathrm{mg} / \mathrm{kg}$ xylazine mixture, catheters were inserted into the trachea, vein, or artery. The hepatic sympathetic nerve or hepatic vagal nerve was identified after incision of the abdominal midline for electrical stimulation. Each nerve was attached to stainless steel bipolar electrodes and quickly fixed with a silicon gel. To avoid stimulating the afferent nerves, the central side of each nerve was cut surgically. After the surgery and stabilization period, electrical stimulation $(14 \mathrm{~V}, 0.5 \mathrm{~ms}, 4 \mathrm{~Hz})$ was applied to each nerve for $5 \mathrm{~min}$. Blood was sampled from the artery before, during, and after nerve stimulation or sham stimulation, and blood glucose was immediately measured using a glucometer (Glucocard G-meter; Arkray).

Biochemical studies. Rats and mice were fasted overnight before ICV injection of vehicle or leptin ( $10 \mu \mathrm{g} / 10 \mu \mathrm{l}$ for rats, $2 \mu \mathrm{g} / 2 \mu \mathrm{l}$ for mice). Thirty minutes after ICV injections, animals were killed by decapitation, and the mediobasal hypothalamus or the ARC was quickly removed and homogenized on ice. To knock down hypothalamic AMPK $\alpha 2$, siRNA targeting AMPK $\alpha 2$ was injected into the third cerebroventricular area in rats as described above. To examine the effects of leptin on AMPK $\alpha 2$, rats were killed $3 \mathrm{~h}$ after injection as described previously (Tanida et al., 2013).

The amount of total protein was measured for each sample by the bicinchoninic acid method (Thermo Fisher Scientific; Smith et al., 1985). 
A total of $10 \mu \mathrm{g}$ (total AMPK, total ERK1/2, total Akt, total p38), $20 \mu \mathrm{g}$ (phospho-ERK1/2, phospho-Akt), or $40 \mu \mathrm{g}$ (phospho-AMPK, phosphop38) of protein lysate per sample was loaded and separated by SDS-PAGE ( $8 \%$ acrylamide) before transfer onto polyvinylidene difluoride membranes. Membranes were then sequentially blocked in a blocking buffer and probed overnight at $4^{\circ} \mathrm{C}$ (with gentle shaking) with primary antibodies (all from Cell Signaling Technology except when indicated) against ERK1/2 (1:1000), phospho-ERK1/2 (1:1000), Akt (1:1000), phosphoAkt (1:1000), p38 MAPK (1:1000), phospho-p38 MAPK (1:1000), AMPK $\alpha 2$ (1:1000; Abcam), AMPK $\alpha$ (1:1000), and phospho-AMPK (1: 1000) flowed by incubation for $1 \mathrm{~h}$ at room temperature with horseradish peroxidase-conjugated secondary antibodies against the molecular weight standard (1:3000; Cell Signaling Technology). Bands of specific proteins were visualized by chemiluminescence (Chemi-Lumi One Super; Nacalai Tesque) and quantified using NIH ImageJ software.

Data analysis. All data were expressed as means \pm SEM. The nerve activity data, measured during baseline and every 5 min thereafter, was analyzed by digital signal processing and appropriate statistical analyses. Percentage changes from baseline values were calculated for each nerve with baseline set at $100 \%$. When comparing the responses of nerve activity between groups, ANOVA with the Bonferroni's post hoc test was used. When comparing the Western blotting data between vehicle and leptin, the Student's $t$ test was used. A $p$ value of $<0.05$ was considered statistically significant.

\section{Results}

To examine the ability of central action of leptin to modulate the activity of the autonomic nerve system subserving the liver, we first assessed whether ICV injection of leptin affects hepatic sympathetic nerve discharge. In anesthetized rats, we found that ICV administration of $10 \mu \mathrm{g}$ of leptin caused a gradual increase in Liv-SNA $\left(F_{(1,10)}=25.684, p=0.0004\right)$, with the maximum response occurring at $235 \mathrm{~min}(168 \pm 9 \%)$ after treatment (Fig. $1 A, B)$. Ganglionic blockade by intravenous administration of hexamethonium bromide abolished the sympathetic activation caused by ICV leptin (Fig. 1C), indicative of efferent sympathetic nerve response. Moreover, the increase in Liv-SNA evoked by ICV leptin is dose dependent $\left(F_{(2,15)}=11.742, p=0.0008\right.$; Fig. $1 D)$. ICV injection of vehicle did not significantly alter Liv-SNA during the $240 \mathrm{~min}$ recording period (Fig. $1 A, B$ ).

Next, we assessed whether leptin affects the activity of the parasympathetic nerve outflow to liver. We found that ICV leptin $(10 \mu \mathrm{g})$ evoked a significant elevation in hepatic vagal nerve activity $\left(t_{(10)}=6.656, p=0.0097\right.$; Fig. $\left.1 E, F\right)$. The increase in Liv-VNA induced by ICV leptin develops slowly over time to reach a maximum of $170 \pm 23 \%$ at $240 \mathrm{~min}$. Liv-VNA was not significantly affected by ICV administration of vehicle (Fig. $1 E, F)$. Thus, CNS leptin signaling modulates the activity of both the sympathetic and parasympathetic nerves subserving the liver.

The relevance of the changes in the activity of the autonomic nervous system to liver functions is indicated by the contrasting changes in blood glucose caused by stimulation of the hepatic sympathetic versus parasympathetic nerves. Indeed, direct stimulation of the hepatic sympathetic nerve increased blood glucose $\left(F_{(1,10)}=20.364, p=0.0011\right)$, whereas stimulation of the hepatic vagal nerve decreased blood glucose in rats $\left(F_{(1,13)}=21.445, p=\right.$ 0.0002; Fig. $1 G)$.

The importance of the hypothalamic ARC in mediating leptin regulation of sympathetic traffic (Rahmouni and Morgan, 2007; Harlan et al., 2011b) and hepatic glucose production (German et al., 2009) prompted us to test whether leptin effects on hepatic autonomic activity emanates from this nucleus. Consistent with such possibility, we found that microinjection of leptin $(0.5 \mu \mathrm{g})$ directly into the ARC increased Liv-SNA in rats $\left(F_{(1,12)}=13.41\right.$, $p=0.0033$; Fig. $2 A-C$ ). Notably, the increase in Liv-SNA after direct microinjection of leptin into the ARC was rapid relative to ICV treatment, reaching $150 \%$ after 65 min of treatment. Likewise, microinjection of leptin into the ARC increased Liv-VNS $\left(F_{(1,8)}=9.149, p=0.0164\right.$; Fig. $\left.2 D, E\right)$. In contrast, intra-ARC administration of vehicle did not alter Liv-SNA (Fig. $2 A, B$ ) or Liv-VNA (Fig. 2D,E). We also assessed whether leptin action in other hypothalamic nuclei such as the VMH alters hepatic autonomic nerve activity. However, we found that direct microinjection of leptin into the VMH had no effect on Liv-SNA $\left(F_{(1,10)}=\right.$ $1.024, p=0.3354$; Fig. $2 B, C)$.

Leptin-induced increase in sympathetic nerve outflow to various tissues/organs such as brown adipose tissue (BAT) and kidney has been observed in various species other than rats, including mice (Harlan et al., 2011a,b). We therefore examined the effect of ICV injection of leptin on Liv-SNA in mice. Similar to the response observed in rats, ICV injection of leptin $(2 \mu \mathrm{g})$ resulted in a gradual increase in Liv-SNA $\left(F_{(1,10)}=11.469, p=\right.$ $0.0069)$, with the greatest elevation occurring at $150 \mathrm{~min}(207 \pm$ $23 \%$; Fig. $3 A, B)$. This response was completely abolished with hexamethonium bromide (Fig. $3 C$ ), indicating the recruitment of efferent fibers. In mice, ICV leptin also increased Liv-SNA in a dose-dependent manner (Fig. 3D). Thus, the hepatic sympathoexcitatory effect of leptin is not limited to rats as it is present in mice as well. Moreover, similar to the observation in rats, in mice direct stimulation of the sympathetic and parasympathetic nerves increased $\left(F_{(1,12)}=8.056, p=0.0149\right)$ and decreased $\left(F_{(1,12)}=\right.$ 7.8758, $p=0.0158$ ) blood glucose, respectively (Fig. $3 E$ ).

Importantly, the effect of leptin on Liv-SNA was absent in $\mathrm{db} / \mathrm{db}$ mice, which lack the " $\mathrm{b}$ " signaling isoform of the leptin receptor LepRb $\left(F_{(3,17)}=3.783, p=0.0301\right.$; Fig. $\left.3 D\right)$, indicating that the response is receptor mediated. Next, we assessed the downstream signaling pathways of the LepRb that mediate leptin control of autonomic activity. Our previous work has implicated both ERK1/2 pathway and PI3K signaling in the CNS in the control of regional sympathetic outflow by leptin (Rahmouni et al., 2009; Harlan et al., 2013). To test the importance of these two pathways in mediating the effect of leptin on Liv-SNA, we used several approaches. First, we confirmed that ICV administration of leptin increases the phosphorylation levels of ERK1/2 $\left(t_{(8)}=\right.$ 6.656, $p=0.0001)$ and Akt $\left(t_{(8)}=3.736, p=0.0057\right)$ in the mediobasal hypothalamus in rats (Fig. $4 A, B$ ). A similar response was noted in mice (Fig. $4 D, E$ ). However, ICV leptin failed to affect the phosphorylation levels of p38MAPK in the mediobasal hypothalamus (rats: $t_{(8)}=0.551, p=0.5961$; mice: $t_{(8)}=0.994$, $p=0.349$; Fig. $4 C, F)$, which is in agreement with our previous study (Rahmouni et al., 2009). We also assessed whether ICV injection of leptin affects the PI3K signaling in the ARC. We found that ICV leptin increased the phosphorylation level of Akt in the ARC of rats $\left(t_{(8)}=6.526, p=0.0001\right.$; Fig. $\left.2 F, G\right)$.

We then used a pharmacological approach to examine the requirement of ERK1/2 and/or PI3K signaling for leptin regulation of hepatic sympathetic nerve outflow. We found that ICV pretreatment with a PI3K inhibitor (LY294002) significantly attenuated leptin-evoked activation of Liv-SNA $\left(\right.$ rats: $F_{(2,12)}=$ $0.9948, p=0.4854$ vs vehicle plus vehicle; mice: $F_{(2,10)}=1.7384$, $p=0.2167$ vs vehicle plus vehicle; Fig. $4 G, H)$. In contrast, ICV pretreatment with a selective inhibitor of either ERK1/2 (U0126) or p38MAPK (SB203580) did not interfere with the ability of ICV leptin to induce hepatic sympathetic activation compared with vehicle pretreatment (Fig. 4G,H).

To study further the signaling pathways underlying the effect of leptin on Liv-SNA, we used mouse models carrying disruption in the various pathways associated with the LepRb signaling. 
A

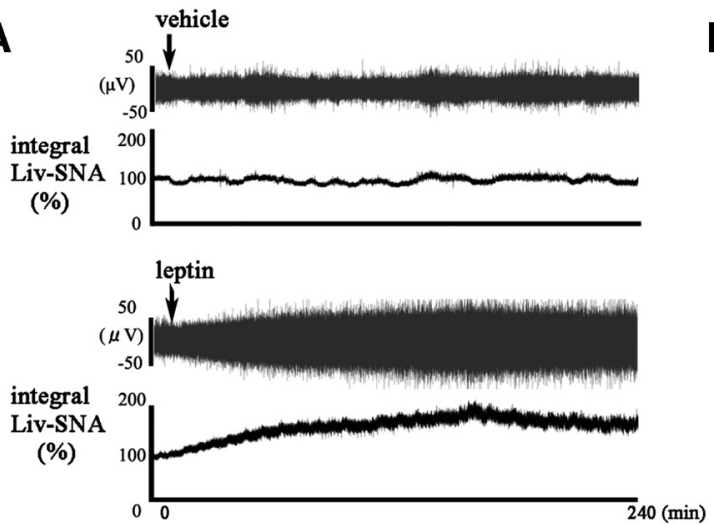

C

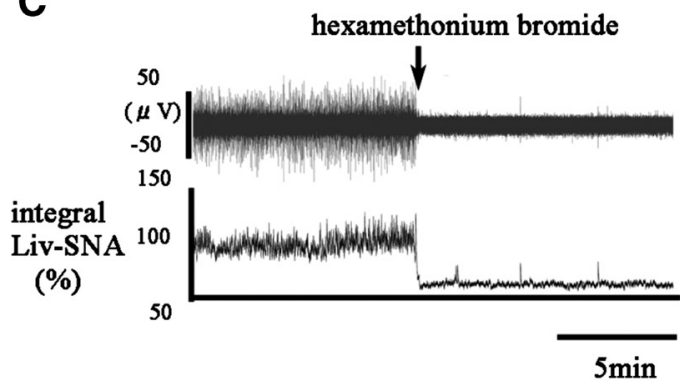

vehicle

E

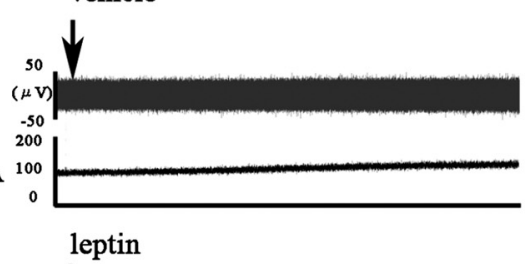

(\%)

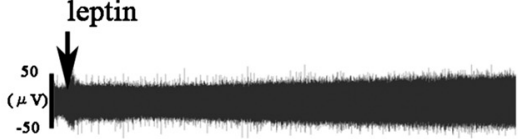

integral

Liv-VNA

(\%)

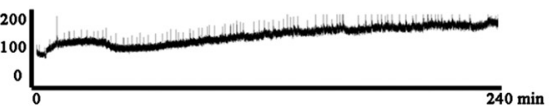

G

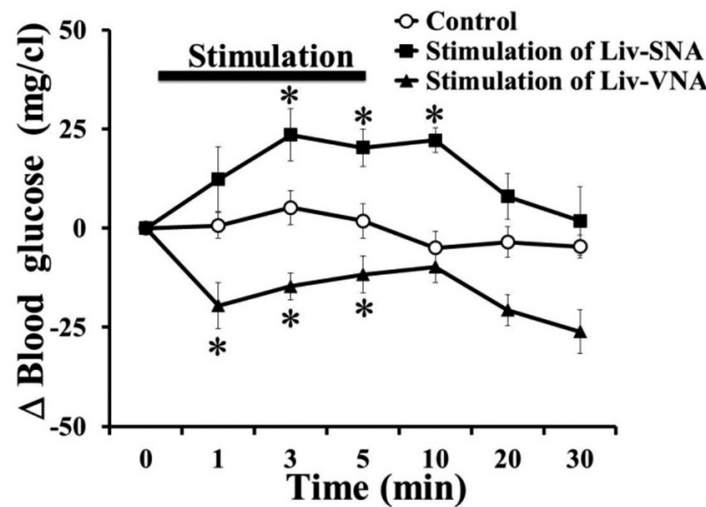

F
B

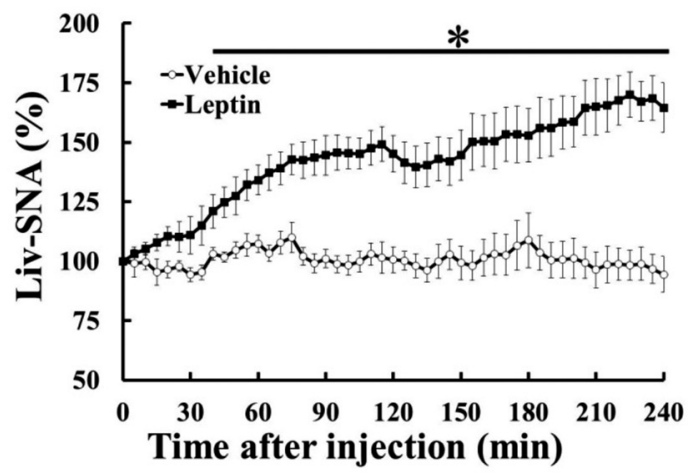

D

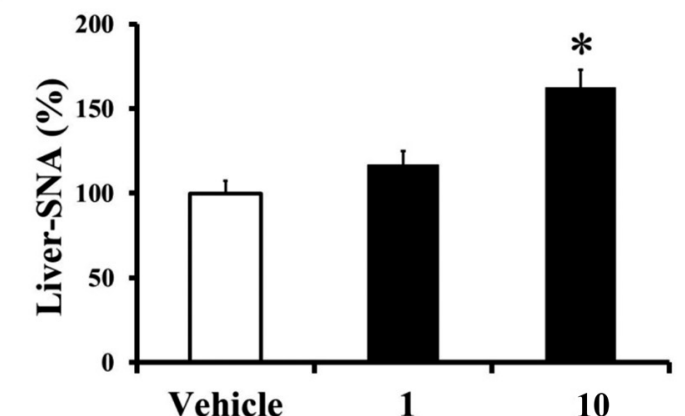

Leptin $(\mu \mathrm{g})$

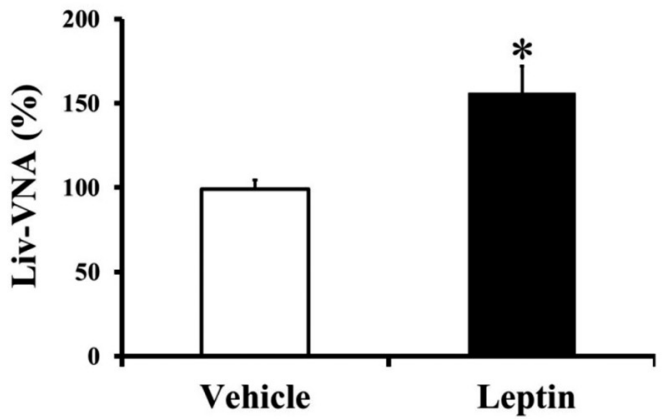

Figure 1. ICV leptin increases hepatic sympathetic and vagal nerve activity in rats. $\boldsymbol{A}, \boldsymbol{B}$, Representative neurograms $(\boldsymbol{A})$ and time course data $(\boldsymbol{B})$ depicting the effect of ICV administration of vehicle and leptin $(10 \mu \mathrm{g})$ on Liv-SNA in rats. C, Effect of intravenous bolus injection of hexamethonium bromide on Liv-SNA response evoked by ICV leptin. D, Dose-response effect of ICV leptin on Liv-SNA (average of last hour of recording is displayed for each group). $\boldsymbol{E}, \boldsymbol{F}$, Representative neurograms $(\boldsymbol{E})$ and average of last hour of recording $(\boldsymbol{F})$ depicting the effect of ICV vehicle and leptin (10 $\mu \mathrm{g}$ ) on Liv-VNA in rats. $\mathbf{G}$, Changes in blood glucose evoked by direct electrical stimulation of the hepatic sympathetic nerve versus parasympathetic nerve relative to sham stimulation (control) in rats. Data are presented as mean \pm SEM; $n=6-7$ per group. ${ }^{*} p<0.05$ versus vehicle or control. 

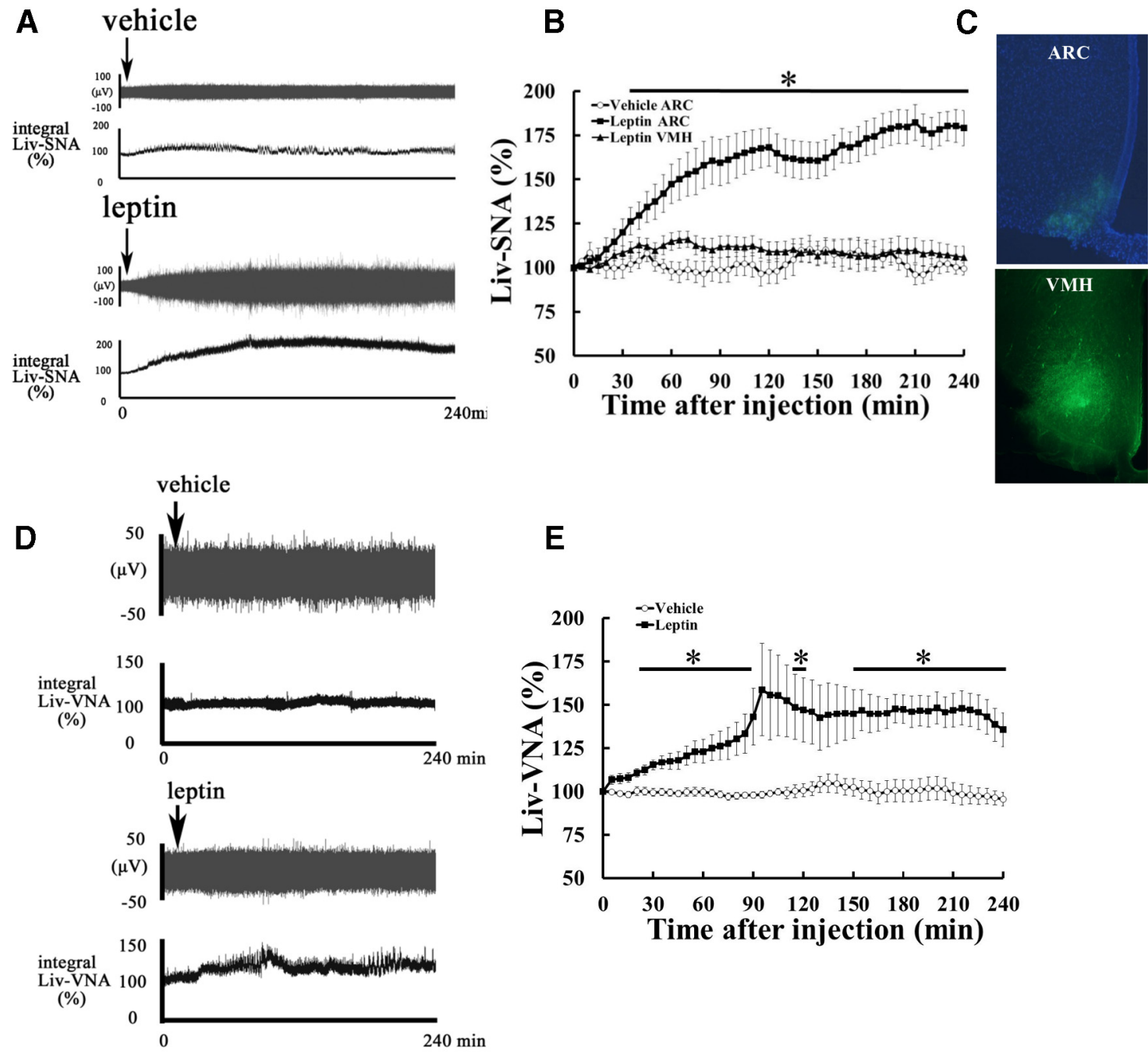

$\mathbf{F}$

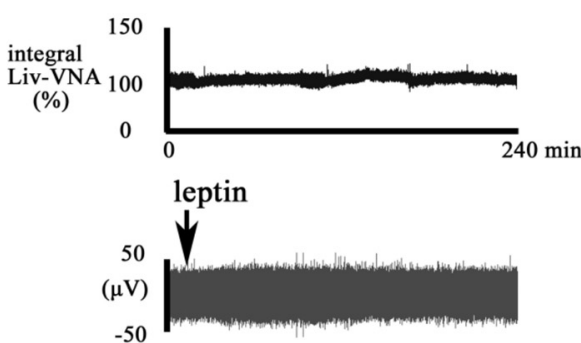

Time after injection (min)

vehicle leptin vehicle leptin

G
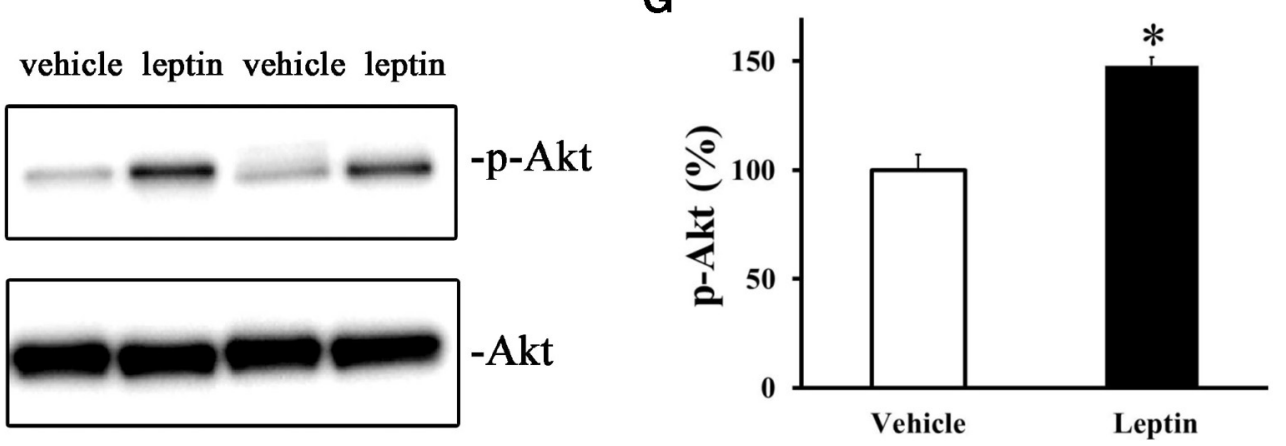

Figure 2. Leptin microinjection into the hypothalamic ARC increases hepatic sympathetic outflow in rats. $\boldsymbol{A}, \boldsymbol{B}$, Representative neurograms $(\boldsymbol{A})$ and time course data ( $\boldsymbol{B})$ depicting the Liv-SNA response to intra-ARC or -VMH injection of vehicle and leptin $(0.5 \mu \mathrm{g})$. C, Microphotographs of coronal rat brain sections showing restricted presence of the dye after comicroinjection with leptin into the ARC (counterstained with DAPI; top) or VMH (bottom). $\boldsymbol{D}, \boldsymbol{E}$, Representative neurograms $(\boldsymbol{D})$ and time course data (E) of Liv-VNA response to intra-ARC injection of vehicle and leptin $(0.5 \mu \mathrm{g})$. $\boldsymbol{F}, \boldsymbol{G}$, Western blot analysis of phosphorylated and total levels of Akt in the ARC 30 min after ICV injection of vehicle or leptin. Data are presented as mean \pm SEM; $n=5-7$ per group. ${ }^{*} p<0.05$ versus vehicle group.

First, we studied $\mathrm{p} 110 \alpha^{\mathrm{D} 933 \mathrm{~A} / \mathrm{WT}}$ mice that carry a knock-in mutation that abrogates $\mathrm{p} 110 \alpha$ kinase activity (Foukas et al., 2006). We previously demonstrated a blunted leptin-induced activation of hypothalamic PI3K signaling in these $\mathrm{p} 110 \alpha^{\mathrm{D} 933 \mathrm{~A} / \mathrm{WT}}$ mice (Harlan et al., 2013). Consistent with pharmacological inhibition, we found that the $\mathrm{p} 110 \alpha^{\mathrm{D} 933 \mathrm{~A} / \mathrm{WT}}$ mice have absent hepatic sympathetic nerve response to ICV leptin $\left(F_{(1,10)}=0.1661, p=\right.$ 0.6921 vs vehicle; Fig. 5 ). Next, we tested the effect of leptin on
Liv-SNA in the $l / l$ knock-in mice, which carry a point mutation resulting in the substitution of the Tyr985 with a Leu residue in the LepRb $\left(\operatorname{Lepr}^{L 985}\right)$ that blocks the recruitment of SHP2 and thus ERK1/2 activation (Björnholm et al., 2007; Harlan et al., 2011a). In line with the pharmacological experiment, the $l / l$ mice exhibited intact liver sympathetic nerve activation in response to ICV leptin $\left(F_{(1,10)}=33.3731, p=0.0004\right.$ vs vehicle; Fig. 5). We also studied the $s / s$ mice that have a mutation at Tyr1138 of 
A

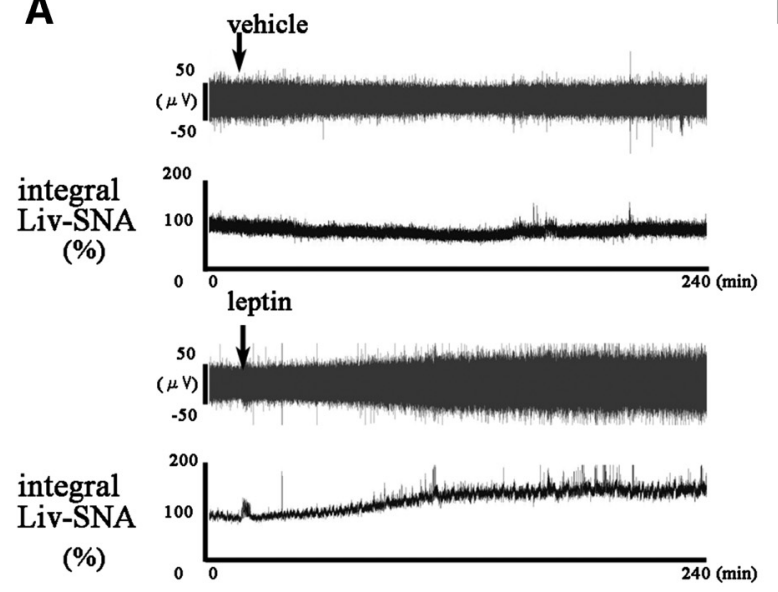

B

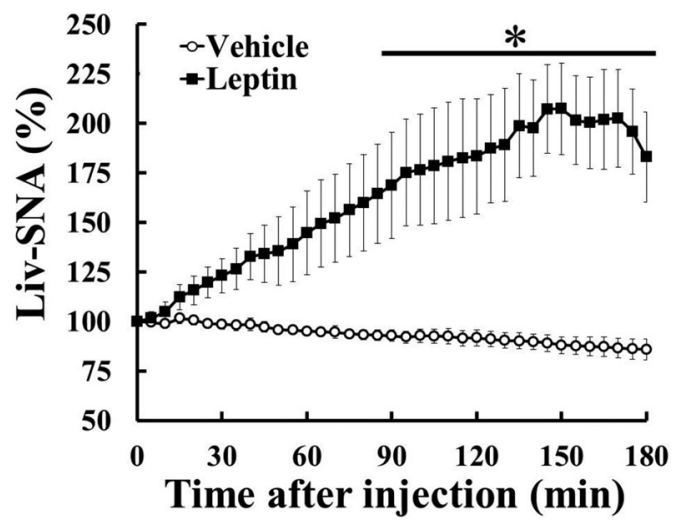

C

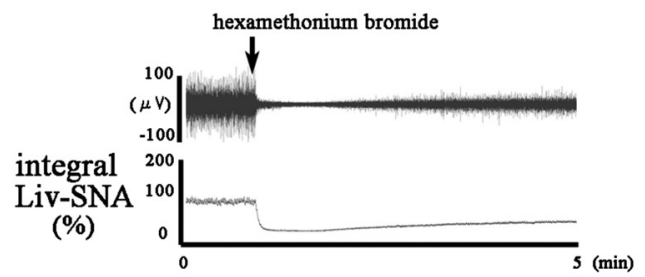

D

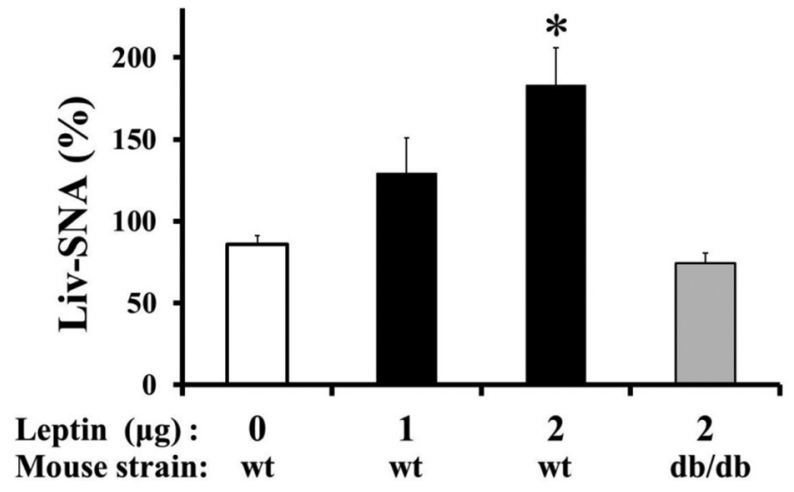

$\mathbf{E}$

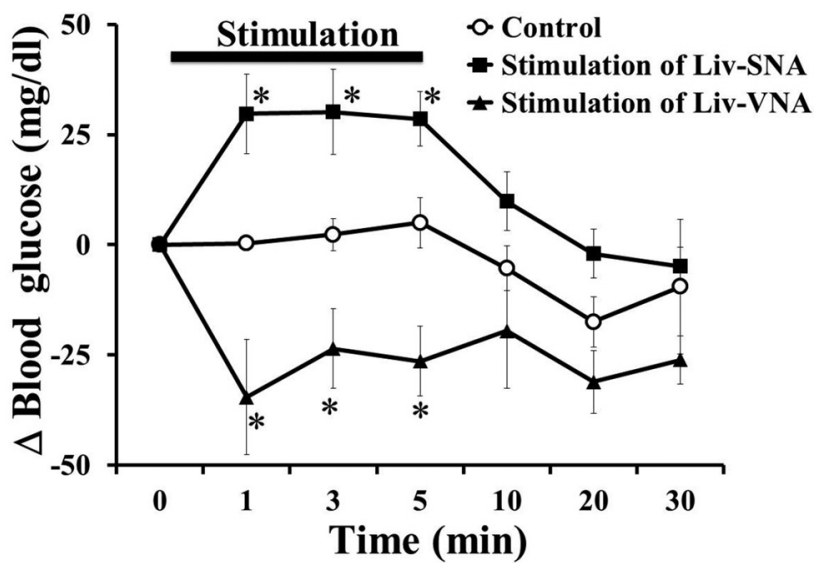

Figure 3. Receptor-mediated hepatic sympathetic activation to ICV leptin in mice. $\boldsymbol{A}, \boldsymbol{B}$, Representative neurograms $(\boldsymbol{A})$ and time course data $(\boldsymbol{B})$ of Liv-SNA response to ICV administration of vehicle and leptin $(2 \mu \mathrm{g})$ in mice. $\boldsymbol{C}$, Representative neurogram showing the suppression of Liv-SNA response to leptin with hexamethonium bromide administered intravenously. $\boldsymbol{D}$, Effect of ICV leptin $(2 \mu \mathrm{g})$ on Liv-SNA in wild-type mice is dose dependent and absent in $\mathrm{db} / \mathrm{db}$ mice, which lack the leptin receptor (average of last hour of recording is displayed for each group). $\boldsymbol{E}$, Changes in blood glucose evoked by direct electrical stimulation of the hepatic sympathetic versus parasympathetic nerves relative to sham stimulation (control) in mice. Data are presented as mean \pm SEM; $n=5-7$ mice per group. ${ }^{*} p<0.05$ versus vehicle or control.

LepRb $\left(\operatorname{Lepr}^{\mathrm{S1138}}\right)$, which disrupts specifically leptin-induced STAT3 signaling (Bates et al., 2003; Harlan et al., 2011a). Interestingly, the $s / s$ mice also displayed unaltered Liv-SNA response to ICV leptin $\left(F_{(1,10)}=14.5269, p=0.0051\right.$ vs vehicle; Fig. 5). Together, these findings implicate PI3K signaling, but not ERK1/2 and STAT3 signaling, as a key downstream pathway in control of hepatic sympathetic outflow by leptin.

We have previously shown the crucial role of AMPK $\alpha 2$ in leptin regulation of sympathetic nerve tone to kidney and white adipose tissue (Tanida et al., 2013). We thus examined the possi- ble involvement of hypothalamic AMPK signaling in leptininduced increase in liver autonomic nerve discharges. We confirmed that ICV leptin suppresses the phosphorylation level of AMPK in the hypothalamus in rats $t_{(8)}=7.353, p=0.0001$; Fig. $6 A, B)$. We then determined the effect of siRNA-mediated knockdown of AMPK $\alpha 2$ in the mediobasal hypothalamus on leptin effects on autonomic nerve activity. Three days after injection of an siRNA targeting AMPK $\alpha 2$ into the third cerebral ventricle, which is anatomically adjacent to the hypothalamus, a significant decrease in AMPK $\alpha 2$ levels in mediobasal hypotha- 
A

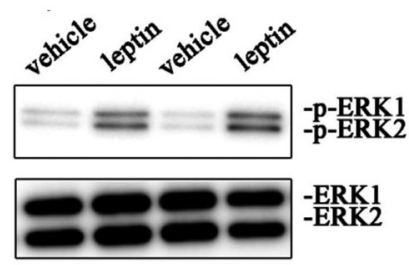

B
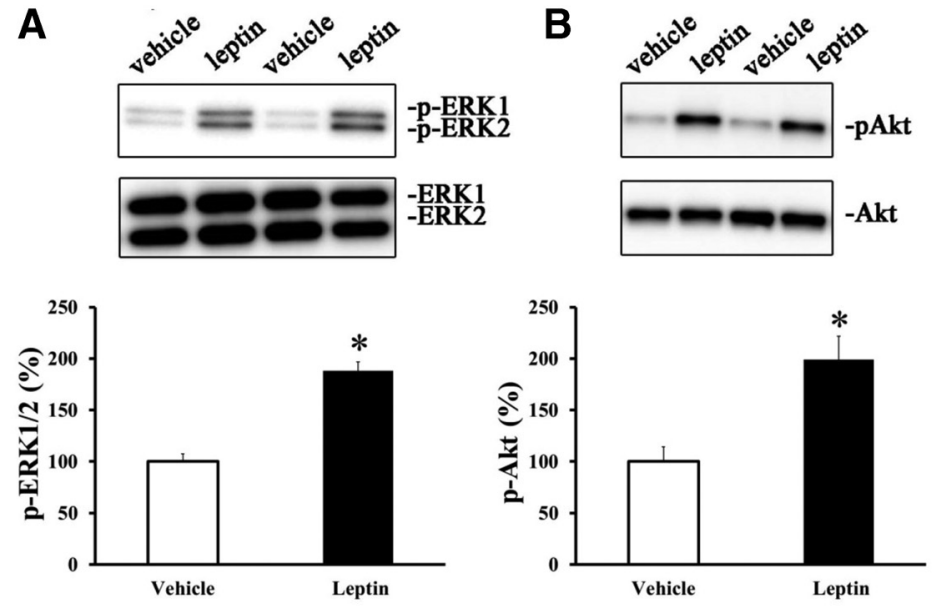

D

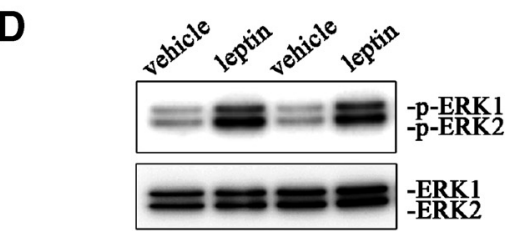

E
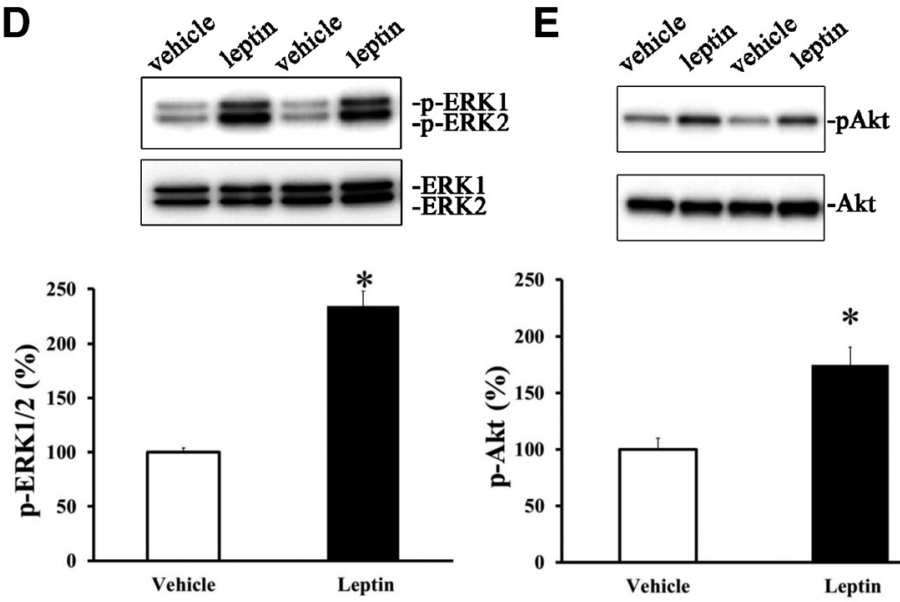

G

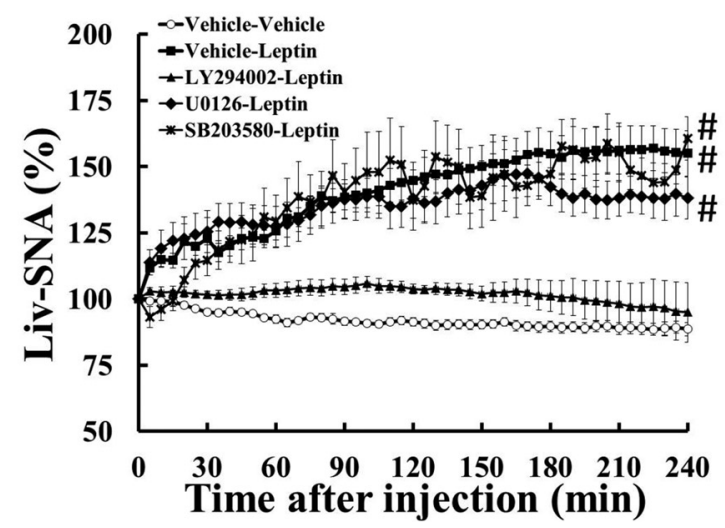

C
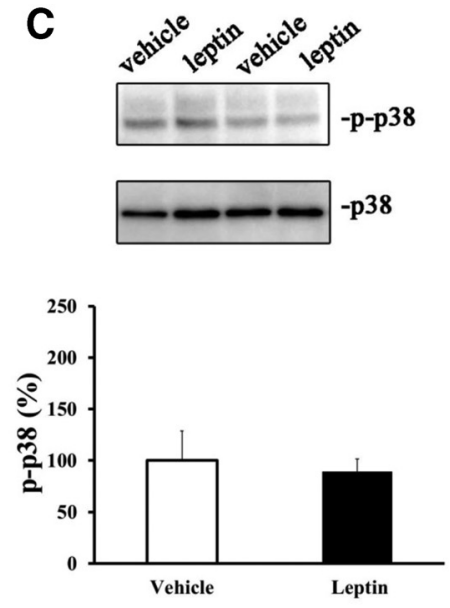

F
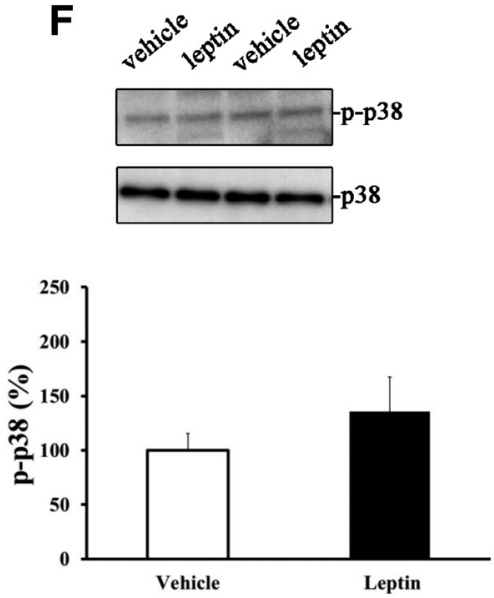

H

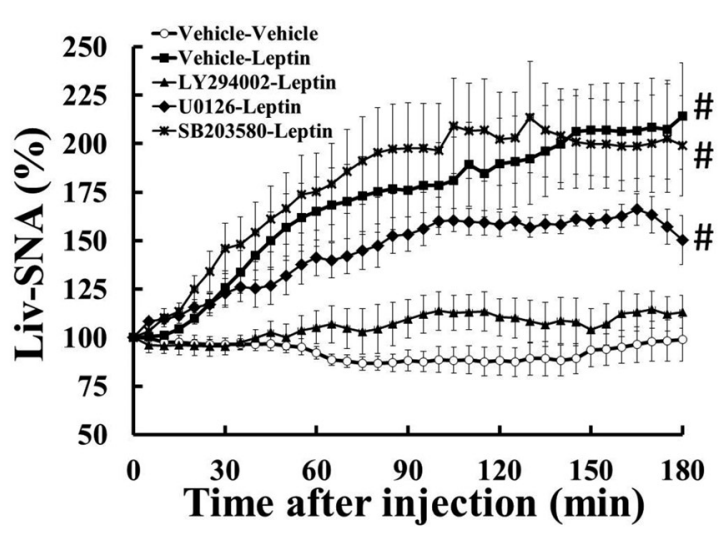

Figure 4. Role of hypothalamic ERK1/2, Akt, and p38 MAPK in mediating hepatic sympathetic nerve response to leptin. $A-F$, Levels of p-ERK1/2 $(A, D), p-A k t(B, E)$, and p-p38 MAPK $(C, F)$ in the hypothalamus 30 min after ICV injection of vehicle and leptin in rats $(10 \mu \mathrm{g} ; \boldsymbol{A}-\mathbf{C})$ or mice $(2 \mu \mathrm{g} ; \boldsymbol{D}-\boldsymbol{F})$. G, $\boldsymbol{H}$, Effects of ICV pretreatment with inhibitors of ERK1/2 (U0126), PI3K (LY294002), or p38 MAPK (SB203580) on hepatic sympathetic response to ICV leptin in rats $(\boldsymbol{G})$ and mice $(\boldsymbol{H})$. Data are presented as mean \pm SEM; $n=5-7$ per group. ${ }^{*} p<0.05$ versus vehicle group; ${ }^{\#} p<0.05$ versus vehicle plus vehicle and LY294002 plus leptin.

lamic explants was noted $\left(t_{(10)}=2.571, p=0.0278\right.$; Fig. $\left.6 C\right)$. However, silencing AMPK $\alpha 2$ did not interfere with the ability of leptin to increase hepatic sympathetic nerve outflow as indicated by the comparable increase in Liv-SNA in response to ICV leptin in rats bearing hypothalamic AMPK $\alpha 2$ knockdown and controls $\left(F_{(2,12)}=0.3699, p=0.9998\right.$; Fig. $\left.6 D\right)$. These findings indicate that AMPK signaling is not involved in the control of Liv-SNA by leptin.
Finally, we examined whether AMPK is involved in the effect of leptin on hepatic parasympathetic nerve outflow. Interestingly, unlike the Liv-SNA response, leptin activation of Liv-VNA was abolished in rats that had AMPK $\alpha 2$ knocked down in the hypothalamus $\left(F_{(2,11)}=12.7056, p=0.0044\right.$; Fig. $\left.6 E\right)$. Notably, inhibition of PI3K with ICV LY294002 pretreatment also blocked the Liv-VNA response evoked by ICV leptin in rats $\left(F_{(2,8)}=\right.$ $0.0194, p=0.8928$ vs vehicle plus vehicle; Fig. $6 F$ ). Thus, the 


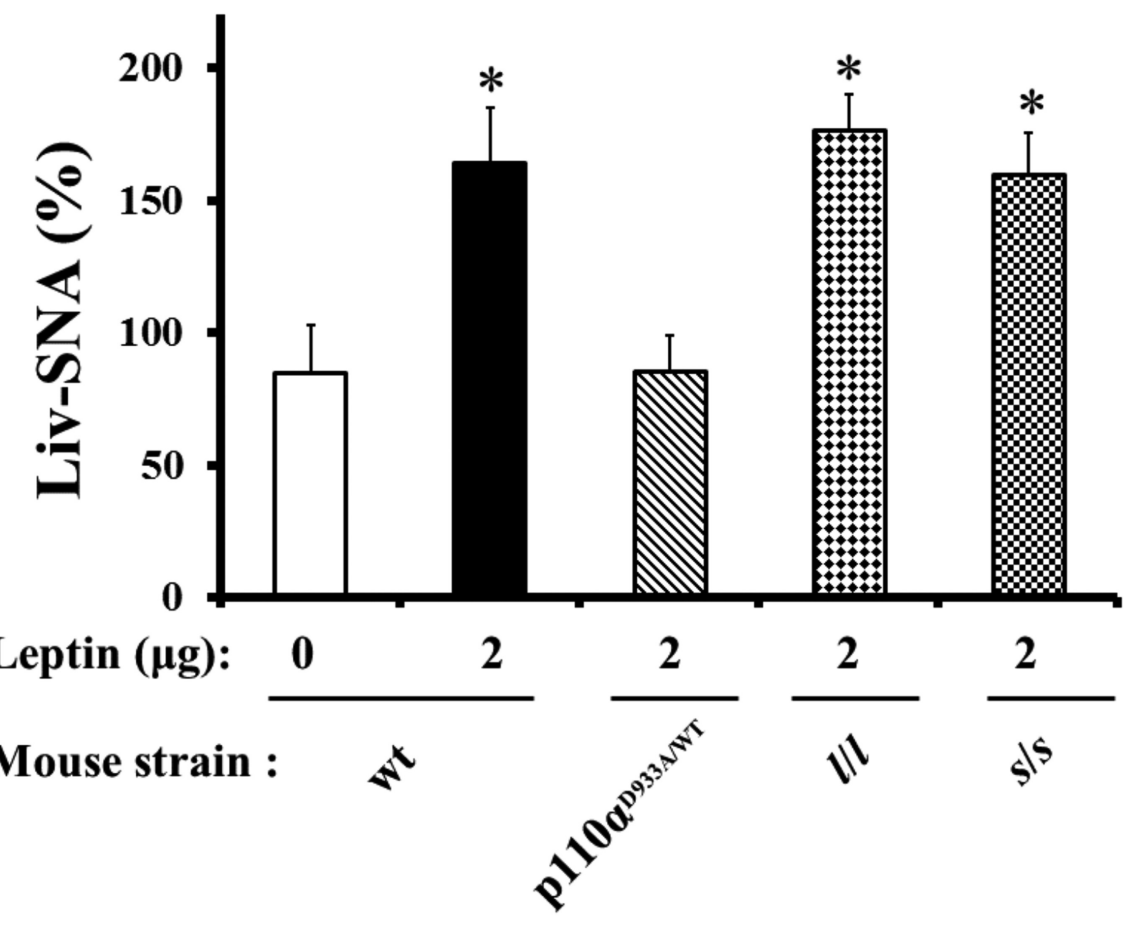

Figure 5. Genetic disruption of the signaling pathways associated with the leptin receptor affect differentially leptin-induced hepatic sympathetic activation. A comparison of Liv-SNA response to ICV leptin $(2 \mu \mathrm{g})$ between wild-type (wt) mice and mice carrying genetic mutations that interfere with leptin activation of PI3K (p110 $\alpha^{\text {D933A/WT }}$ mice), ERK1/2 (I// mice), or STAT3 (s/s mice) is shown. Data are presented as mean $\pm \mathrm{SEM} ; n=5-7$ animals per group. ${ }^{*} p<0.05$ versus wt group.

hypothalamic PI3K-AMPK axis mediates the effects of leptin on liver vagal nerve activity.

\section{Discussion}

In the present study, we investigated the effects of CNS leptin signaling on the activity of the autonomic nervous system subserving the liver. This investigation yielded several new findings. First, our study provides direct evidence that CNS action of leptin increases both sympathetic and parasympathetic traffic to the liver. Second, we show that leptin microinjection into the hypothalamic ARC, but not into the $\mathrm{VMH}$, causes a rapid increase in liver sympathetic and parasympathetic traffic highlighting the importance of the ARC in mediating the effect of leptin on hepatic autonomic outflow. Third, our data demonstrate that the hepatic sympathoexcitatory effect of CNS leptin is receptor mediated and requires PI3K signaling. Finally, we show that CNS leptin stimulation of hepatic vagal nerve outflow involves PI3K as well as AMPK. The contrasting change in blood glucose after direct stimulation of hepatic sympathetic and vagal nerves highlights the relevance of modulating the autonomic nerve activity subserving the liver and is consistent with the well known role of the autonomic nervous system as a major regulator of hepatic functions (Jensen et al., 2013).

Together, these findings provide mechanistic insights into the control of liver function by CNS leptin signaling.

Several lines of evidences have implicated CNS leptin in the regulation of liver function, such as glucose production and lipid synthesis (Morton and Schwartz, 2011; Warne et al., 2011; Coppari and Bjørbæk, 2012). CNS leptin was found to increase liver norepinephrine turnover indicative of hepatic sympathetic nerve activation (Warne et al., 2011). Our current study provides direct evidence that CNS leptin increases the firing of the sympathetic nerves subserving the liver. Abolition of the hepatic sympathetic response evoked by leptin with ganglionic blockade indicates that the observed sympathetic excitation is generated primarily within the CNS rather than in postganglionic sympathetic neurons. Our finding that leptin increases hepatic vagal nerve activity is also in line with the requirement of the vagal nerves for the control of hepatic insulin sensitivity by leptin (German et al., 2009). The ability of leptin to increase the activity of both the sympathetic and parasympathetic nerves subserving the liver may not be expected given the dualism of these two branches of the autonomic nervous system. However, the bidirectional effects of hepatic sympathetic versus vagal nerve stimulation on blood glucose show the opposing consequences of activating these two arms of the hepatic autonomic nervous system.

The leptin receptor is enriched in the hypothalamic ARC, and the importance of leptin action in the ARC in the modulation of physiological processes including liver function is established (Coppari et al., 2005; German et al., 2009; Morton and Schwartz, 2011). Moreover, we previously demonstrated that ARC leptin receptor is required for leptin-induced sympathetic activation to the kidney and BAT (Harlan et al., 2011b). In the present study, we found that leptin microinjection into the hypothalamic $\mathrm{ARC}$, but not the VMH, caused a rapid increase in hepatic sympathetic outflow, pointing to the importance of this nucleus in mediating the effect of leptin on hepatic sympathetic outflow. The anatomic aspects of the neural connections between the ARC and liver have been characterized previously using viral retrograde tracing techniques. Indeed, injection of the pseudorabies virus into the liver infected neurons in specific brain sites including the ARC (la Fleur et al., 2000; Stanley et al., 2010). Interestingly, within the ARC, only the subset of neurons expressing pro-opiomelanocortin was infected after liver injection of pseudorabies virus, suggesting that projections from the ARC to the liver originate from these neurons (Stanley et al., 2010). These studies provide a neuroanatomical basis for the control of liver sympathetic outflow by leptin action in the ARC. However, the ARC may not be the sole nucleus mediating leptin effects on hepatic sympathetic outflow. There are many other hypothalamic and extrahypothalamic nuclei equipped with the leptin receptor that projects to the liver (la Fleur et al., 2000; Stanley et al., 2010). Additional studies are also needed to examine the role of the ARC and/or other nuclei in mediating the vagal nerve response evoked by leptin.

Leptin binding to its receptor initiates myriad intracellular events that are involved in the control of physiological processes, including sympathetic nerve traffic. Indeed, ERK1/2 underlies leptin control of sympathetic outflow to thermogenic BAT, whereas PI3K mediates leptin regulation of sympathetic traffic to the kidney (Rahmouni et al., 2009; Harlan et al., 2013). Here, we show that PI3K is important for leptin control of sympathetic outflow subserving the liver. Pharmacological inhibition of PI3K signaling blocked leptin-induced increase in liver sympathetic traffic in rats and mice. Likewise, genetic blockade of PI3K activity ( $110 \alpha^{\mathrm{D} 933 \mathrm{~A} / \mathrm{WT}}$ mice) abolished the ability of CNS leptin to 
A

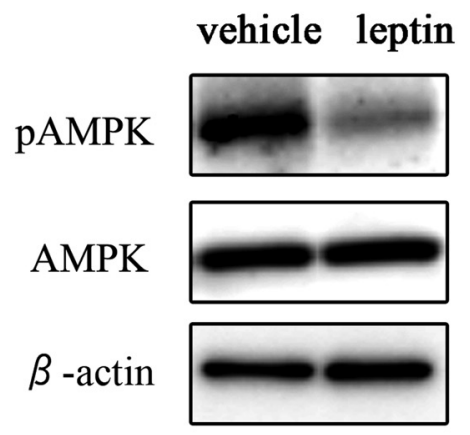

C
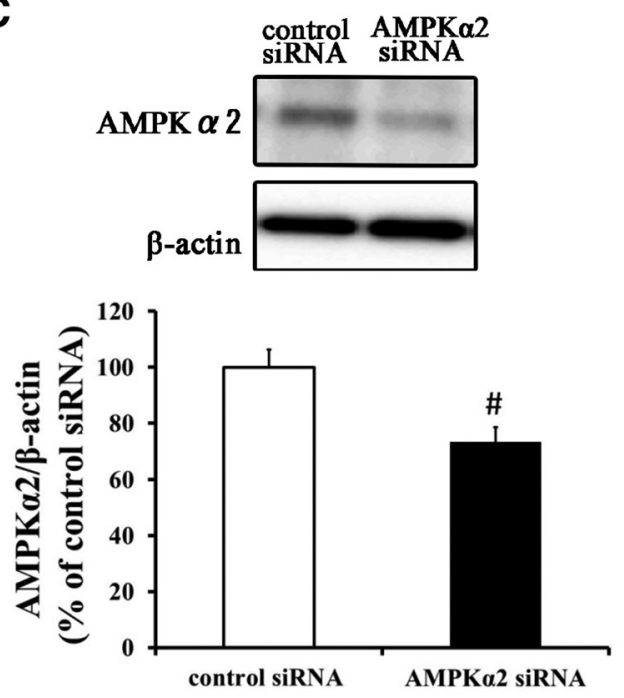

$\mathbf{E}$

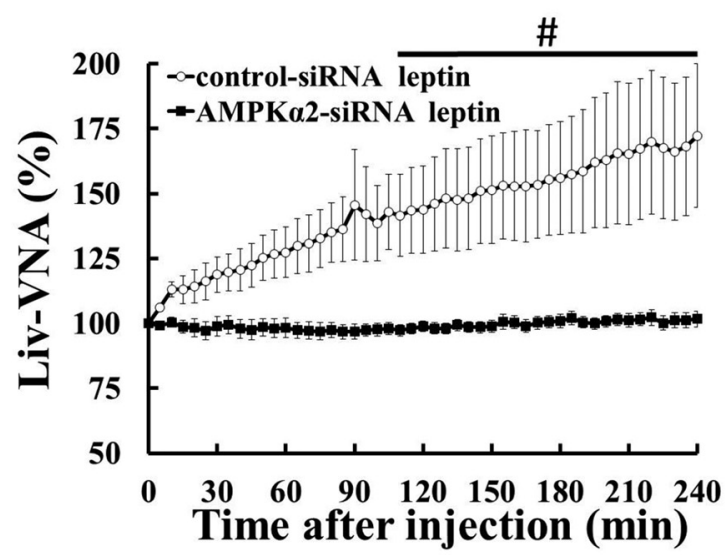

B

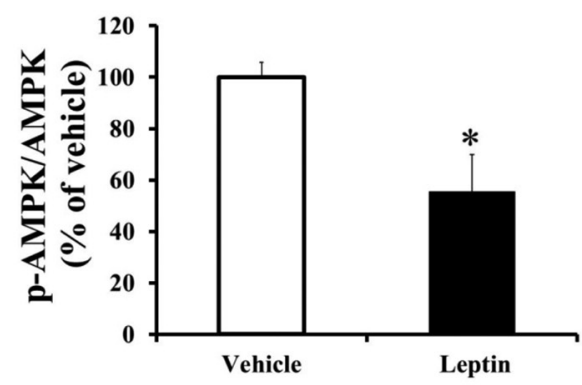

D

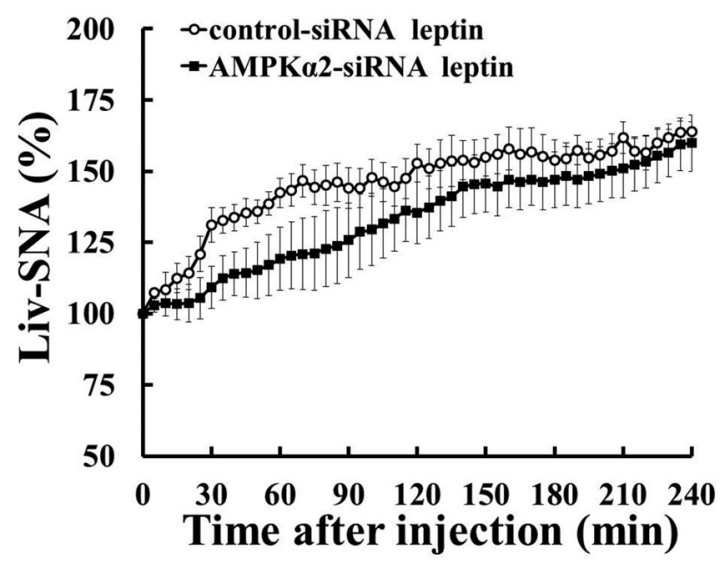

$\mathbf{F}$

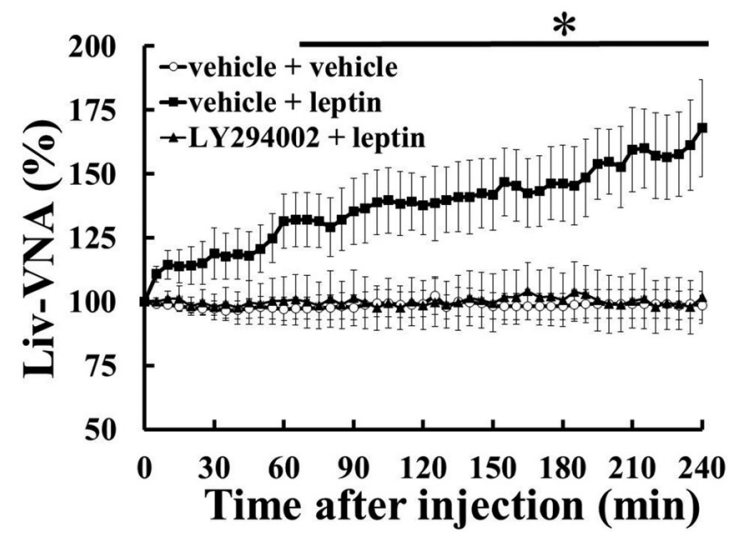

Figure 6. Hypothalamic AMPK-PI3K axis mediate the hepatic vagal nerve response to leptin. $A, B$, Effect of ICV leptin $(10 \mu \mathrm{g})$ on phosphorylated levels of AMPK $\alpha$ in the hypothalamus by Western blot in rats (with total AMPK $\alpha$ and $\beta$-actin used as loading controls). C, Effect of third cerebral ventricle administration of an siRNA against AMPK $\alpha 2$ on the protein expression levels of AMPK $\alpha$ in the mediobasal hypothalamus in rats. $\boldsymbol{D}$, Time course of Liv-SNA response to ICV leptin $(10 \mu \mathrm{g})$ in control-siRNA- and AMPK $\alpha 2$-siRNA-treated rats. $\boldsymbol{E}$, Time course of Liv-VNA response to ICV leptin in control-siRNA- and AMPK $\alpha 2$-siRNA-treated rats. $\boldsymbol{F}$, Effects of PI3K inhibition (LY294002) on hepatic vagal nerve response to ICV leptin (10 $\mu \mathrm{g})$ in rats. Data were presented as mean \pm SEM; $n=5-7$ per group. ${ }^{*} p<0.05$ versus vehicle group; ${ }^{*} p<0.05$ versus control-siRNA group.

increase hepatic sympathetic nerve traffic. Our data are consistent with the previous report demonstrating blunted CNS leptin's effect on liver norepinephrine levels in mice that have PI3K signaling inhibited in the LepRb-containing neurons by overexpressing a phosphatase [phosphatase and tensin homolog (PTEN)] that reverses kinase activity of PI3K (Warne et al., 2011).

On the other hand, the hepatic sympathetic effect of leptin was not significantly altered by ERK inhibition. The dispensability of
ERK1/2 signaling for the leptin control of liver sympathetic outflow was further confirmed in $l / l$ mice that have the LepRbERK1/2 interrupted (Björnholm et al., 2007). The $s / s$ mice bearing disruption of the LepRb-STAT3 pathway (Bates et al., 2003) also displayed unaltered hepatic sympathetic response to leptin indicating that STAT3 is not involved in the control of liver sympathetic outflow by leptin. Together, these findings indicate that only PI3K is required for leptin regulation of hepatic sympa- 
thetic nerve traffic. Our finding that ICV injection of leptin increased PI3K signaling, as indicated by the increased phosphoAkt levels, in the ARC raises the possibility that central leptininduced sympathetic excitation to the liver is mediated by PI3K in the ARC. It is also interesting to note that PI3K inhibition attenuated the vagal nerve response evoked by leptin, pointing to this signaling pathway as a critical regulator of both branches of the autonomic nervous system subserving the liver.

Several studies have shown that PI3K is required for the rapid and acute changes in neuronal activity evoked by leptin. In addition, PI3K has been implicated in the modulation of gene expression (e.g., neuropeptide $\mathrm{Y}$ and agouti-related protein) by leptin (Morrison et al., 2005), perhaps through inactivation of the FoxO-1 transcription factor (Kitamura et al., 2006; Plum et al., 2007). Consistent with the effect of leptin on the SNA subserving other beds (Rahmouni et al., 2009), the hepatic SNA and VNA responses to leptin are slow in onset. The slowly developing autonomic responses to leptin raise the possibility that it may require changes in gene expression. Alternatively, this may relate to the complex neural network and downstream neuropeptides that are involved in mediating leptin effects (Myers et al., 2008; Morton and Schwartz, 2011; Coppari and Bjørbæk, 2012).

AMPK signaling has emerged as an important mediator in the regulation of physiological processes by leptin action in the hypothalamus. Consistent with our previous study (Tanida et al., 2013), we demonstrate that ICV leptin inhibits AMPK phosphorylation in rats. In addition, we previously found that leptininduced sympathetic activation to kidney and white adipose tissue was eliminated after silencing hypothalamic AMPK $\alpha 2$ in rats (Tanida et al., 2013). This evidence prompted us to examine whether the Liv-SNA response to ICV leptin also requires hypothalamic AMPK $\alpha 2$. We found that leptin-induced sympathetic activation to the liver was not altered after knockdown of AMPK $\alpha 2$ in the hypothalamus. On the other hand, hepatic vagal nerve stimulation evoked by leptin was attenuated after silencing hypothalamic AMPK $\alpha 2$.

Notably, the PI3K-AMPK axis has recently been involved in mediating the acute anorectic effect of leptin (Dagon et al., 2012). These findings are in agreement with our present finding that this PI3K-AMPK axis mediates the leptin-induced increase in hepatic vagal nerve activity. However, if PI3K and AMPK are linked in leptin receptor signaling, it is not clear why PI3K, but not AMPK, is required for leptin-induced increase in hepatic sympathetic traffic. We speculate that this may be caused by leptin action on different neuronal populations (with variations in the involvement of PI3K and AMPK in LepRb signaling) to regulate sympathetic versus vagal activity. Consistent with such possibility, neuroanatomical studies have shown that there are separate sympathetic and parasympathetic neurons in the hypothalamus that project to the liver (Buijs et al., 2003). However, additional studies are needed to test this further and reveal the identity of the autonomic neurons in the hypothalamus that mediate the effect of leptin on hepatic sympathetic vs vagal activity.

In conclusion, our data show that CNS action of leptin regulates nerve outflow to the liver by stimulating both branches of the autonomic nervous system, increasing the activity of sympathetic and parasympathetic nerves. We also demonstrate the importance of the intracellular signaling associated with the LepRb, particularly PI3K and AMPK, in mediating the hepatic sympathetic and vagal responses evoked by leptin.

\section{References}

Bates SH, Stearns WH, Dundon TA, Schubert M, Tso AW, Wang Y, Banks AS, Lavery HJ, Haq AK, Maratos-Flier E, Neel BG, Schwartz MW, Myers MG $\mathrm{Jr}$ (2003) STAT3 signalling is required for leptin regulation of energy balance but not reproduction. Nature 421:856-859. CrossRef Medline

Björnholm M, Münzberg H, Leshan RL, Villanueva EC, Bates SH, Louis GW, Jones JC, Ishida-Takahashi R, Bjørbaek C, Myers MG Jr (2007) Mice lacking inhibitory leptin receptor signals are lean with normal endocrine function. J Clin Invest 117:1354-1360. CrossRef Medline

Buijs RM, la Fleur SE, Wortel J, Van Heyningen C, Zuiddam L, Mettenleiter TC, Kalsbeek A, Nagai K, Niijima A (2003) The suprachiasmatic nucleus balances sympathetic and parasympathetic output to peripheral organs through separate preautonomic neurons. J Comp Neurol 464:36-48. CrossRef Medline

Chen H, Charlat O, Tartaglia LA, Woolf EA, Weng X, Ellis SJ, Lakey ND, Culpepper J, Moore KJ, Breitbart RE, Duyk GM, Tepper RI, Morgenstern JP (1996) Evidence that the diabetes gene encodes the leptin receptor: identification of a mutation in the leptin receptor gene in $\mathrm{db} / \mathrm{db}$ mice. Cell 84:491-495. CrossRef Medline

Coppari R, Bjørbæk C (2012) Leptin revisited: its mechanism of action and potential for treating diabetes. Nat Rev Drug Discov 11:692-708. CrossRef Medline

Coppari R, Ichinose M, Lee CE, Pullen AE, Kenny CD, McGovern RA, Tang V, Liu SM, Ludwig T, Chua SC Jr, Lowell BB, Elmquist JK (2005) The hypothalamic arcuate nucleus: a key site for mediating leptin's effects on glucose homeostasis and locomotor activity. Cell Metab 1:63-72. CrossRef Medline

Dagon Y, Hur E, Zheng B, Wellenstein K, Cantley LC, Kahn BB (2012) p70S6 kinase phosphorylates AMPK on serine 491 to mediate leptin's effect on food intake. Cell Metab 16:104-112. CrossRef Medline

Foukas LC, Claret M, Pearce W, Okkenhaug K, Meek S, Peskett E, Sancho S, Smith AJ, Withers DJ, Vanhaesebroeck B (2006) Critical role for the p110 alpha phosphoinositide-3-OH kinase in growth and metabolic regulation. Nature 441:366-370. CrossRef Medline

Friedman JM, Halaas JL (1998) Leptin and the regulation of body weight in mammals. Nature 395:763-770. CrossRef Medline

Fujikawa T, Chuang JC, Sakata I, Ramadori G, Coppari R (2010) Leptin therapy improves insulin-deficient type 1 diabetes by CNS-dependent mechanisms in mice. Proc Natl Acad Sci U S A 107:17391-17396. CrossRef Medline

Gautron L, Elmquist JK (2011) Sixteen years and counting: an update on leptin in energy balance. J Clin Invest 121:2087-2093. CrossRef Medline

German J, Kim F, Schwartz GJ, Havel PJ, Rhodes CJ, Schwartz MW, Morton GJ (2009) Hypothalamic leptin signaling regulates hepatic insulin sensitivity via a neurocircuit involving the vagus nerve. Endocrinology 150: 4502-4511. CrossRef Medline

Harlan SM, Morgan DA, Dellsperger DJ, Myers MG Jr, Mark AL, Rahmouni K (2011a) Cardiovascular and sympathetic effects of disrupting tyrosine 985 of the leptin receptor. Hypertension 57:627-632. CrossRef Medline

Harlan SM, Morgan DA, Agassandian K, Guo DF, Cassell MD, Sigmund CD, Mark AL, Rahmouni K (2011b) Ablation of the leptin receptor in the hypothalamic arcuate nucleus abrogates leptin-induced sympathetic activation. Circ Res 108:808-812. CrossRef Medline

Harlan SM, Guo DF, Morgan DA, Fernandes-Santos C, Rahmouni K (2013) Hypothalamic mTORC1 signaling controls sympathetic nerve activity and arterial pressure and mediates leptin effects. Cell Metab 17:599-606. CrossRef Medline

Hidaka S, Yoshimatsu H, Kondou S, Tsuruta Y, Oka K, Noguchi H, Okamoto K, Sakino H, Teshima Y, Okeda T, Sakata T (2002) Chronic central leptin infusion restores hyperglycemia independent of food intake and insulin level in streptozotocin-induced diabetic rats. FASEB J 16:509518. CrossRef Medline

Hilzendeger AM, Morgan DA, Brooks L, Dellsperger D, Liu X, Grobe JL, Rahmouni K, Sigmund CD, Mark AL (2012) A brain leptin-renin angiotensin system interaction in the regulation of sympathetic nerve activity. Am J Physiol Heart Circ Physiol 303:H197-H206. CrossRef Medline

Jensen KJ, Alpini G, Glaser S (2013) Hepatic nervous system and neurobiology of the liver. Compr Physiol 3:655-665. CrossRef Medline

Kitamura T, Feng Y, Kitamura YI, Chua SC Jr, Xu AW, Barsh GS, Rossetti L, Accili D (2006) Forkhead protein FoxO1 mediates Agrp-dependent effects of leptin on food intake. Nat Med 12:534-540. CrossRef Medline

la Fleur SE, Kalsbeek A, Wortel J, Buijs RM (2000) Polysynaptic neural path- 
ways between the hypothalamus, including the suprachiasmatic nucleus, and the liver. Brain Res 871:50-56. CrossRef Medline

López M, Varela L, Vázquez MJ, Rodríguez-Cuenca S, González CR, Velagapudi VR, Morgan DA, Schoenmakers E, Agassandian K, Lage R, Martínez de Morentin PB, Tovar S, Nogueiras R, Carling D, Lelliott C, Gallego R, Oresic M, Chatterjee K, Saha AK, Rahmouni K, et al. (2010) Hypothalamic AMPK and fatty acid metabolism mediate thyroid regulation of energy balance. Nat Med 16:1001-1008. CrossRef Medline

Minokoshi Y, Alquier T, Furukawa N, Kim YB, Lee A, Xue B, Mu J, Foufelle F, Ferré P, Birnbaum MJ, Stuck BJ, Kahn BB (2004) AMP-kinase regulates food intake by responding to hormonal and nutrient signals in the hypothalamus. Nature 428:569-574. CrossRef Medline

Morrison CD, Morton GJ, Niswender KD, Gelling RW, Schwartz MW (2005) Leptin inhibits hypothalamic Npy and Agrp gene expression via a mechanism that requires phosphatidylinositol 3-OH-kinase signaling. Am J Physiol Endocrinol Metab 289:E1051-E1057. CrossRef Medline

Morton GJ, Schwartz MW (2011) Leptin and the central nervous system control of glucose metabolism. Physiol Rev 91:389-411. CrossRef Medline

Myers MG, Cowley MA, Münzberg H (2008) Mechanisms of leptin action and leptin resistance. Annu Rev Physiol 70:537-556. CrossRef Medline

Paxinos G, Watson C (2005) The rat brain in stereotaxic coordinates. San Diego: Academic.

Plum L, Rother E, Münzberg H, Wunderlich FT, Morgan DA, Hampel B, Shanabrough M, Janoschek R, Könner AC, Alber J, Suzuki A, Krone W, Horvath TL, Rahmouni K, Brüning JC (2007) Enhanced leptinstimulated Pi3k activation in the CNS promotes white adipose tissue transdifferentiation. Cell Metab 6:431-445. CrossRef Medline
Rahmouni K, Morgan DA (2007) Hypothalamic arcuate nucleus mediates the sympathetic and arterial pressure responses to leptin. Hypertension 49:647-652. CrossRef Medline

Rahmouni K, Sigmund CD, Haynes WG, Mark AL (2009) Hypothalamic ERK mediates the anorectic and thermogenic sympathetic effects of leptin. Diabetes 58:536-542. CrossRef Medline

Smith PK, Krohn RI, Hermanson GT, Mallia AK, Gartner FH, Provenzano MD, Fujimoto EK, Goeke NM, Olson BJ, Klenk DC (1985) Measurement of protein using bicinchoninic acid. Anal Biochem 150:76-85. CrossRef Medline

Stanley S, Pinto S, Segal J, Pérez CA, Viale A, DeFalco J, Cai X, Heisler LK, Friedman JM (2010) Identification of neuronal subpopulations that project from hypothalamus to both liver and adipose tissue polysynaptically. Proc Natl Acad Sci U S A 107:7024-7029. CrossRef Medline

Tanida M, Yamamoto N, Shibamoto T, Rahmouni K (2013) Involvement of hypothalamic AMP-activated protein kinase in leptin-induced sympathetic nerve activation. PLoS One 8:e56660. CrossRef Medline

Toda C, Shiuchi T, Kageyama H, Okamoto S, Coutinho EA, Sato T, Okamatsu-Ogura Y, Yokota S, Takagi K, Tang L, Saito K, Shioda S, Minokoshi Y (2013) Extracellular signal-regulated kinase in the ventromedial hypothalamus mediates leptin-induced glucose uptake in red-type skeletal muscle. Diabetes 62:2295-2307. CrossRef Medline

Warne JP, Alemi F, Reed AS, Varonin JM, Chan H, Piper ML, Mullin ME, Myers MG Jr, Corvera CU, Xu AW (2011) Impairment of central leptin-mediated PI3K signaling manifested as hepatic steatosis independent of hyperphagia and obesity. Cell Metab 14:791-803. CrossRef Medline 